\title{
Functional approach to sediment reworking by gallery-forming macrobenthic organisms: modeling and application with the polychaete Nereis diversicolor
}

\author{
Frédérique François $^{1, *}$, Magali Gerino ${ }^{2}$, Georges Stora $^{3}$, Jean-Pierre Durbec ${ }^{3}$, \\ Jean-Christophe Poggiale ${ }^{3}$ \\ ${ }^{1}$ Observatoire Océanologique de Banyuls, Université Pierre et Marie Curie (Paris VI), CNRS, Laboratoire Arago, BP 44, \\ 66651 Banyuls sur mer cedex, France \\ ${ }^{2}$ Centre d'Ecologie des Systèmes Aquatiques Continentaux, 118 route de Narbonne, 31062 Toulouse cedex, France \\ ${ }^{3}$ Laboratoire d'Océanographie et de Biogéochimie, Centre d'Océanologie de Marseille, Campus de Lunimy, Case 901, \\ 163 avenue de Luminy, 13288 Marseille cedex 09, France
}

\begin{abstract}
A mechanistic model has been developed to characterize and quantify sediment-mixing due to macrobenthic organisms that construct gallery systems. The mixing model is time- and spacedependent and employs ordinary differential equations. It uses (1) biological parameters - the size of the bioturbated zone, rate of biodiffusion and rate of biotransport; (2) physical parametes - output to the water-column coefficient and rate of physical mixing due to local water currents; and (3) biogeochemical parameters - decay rate of the tracer. This gallery-diffusor model is based on a combination of 2 processes: biodiffusion in the sediment layer containing very dense gallery systems, and biotransport in the region of tube bottoms. The performance of this gallery-diffusor model is compared with that of the biodiffusor model classically used to describe mixing of such organisms. Both models are applied to conservative tracer profiles measured in laboratory experiments with the polychaete Nereis diversicolor. Our new model provides mechanisms to describe and explain the tracer-profile shapes observed in sediments. It includes rapid particle transport from the upper layer of the sediment to the tube bottom zone, which is not taken into account with the biodiffusor model but which is of great importance in understanding the processes of organic matter degradation in the sedimentary column. It also makes possible the accurate quantification of the different components of the mixing process of an organism (in this study, the polychaete $N$. diversicolor). The gallery-diffusor model constitutes 1 of 5 elementary components in a global bioturbation model that allows the study, quantification and prediction of sediment reworking by macrobenthic communities according to their functional group and composition and/or to the specific characteristics of the individual organisms.
\end{abstract}

KEY WORDS: Bioturbation · Nereis diversicolor $\cdot$ Model $\cdot$ Functional groups $\cdot$ Macrobenthos

\section{INTRODUCTION}

Bioturbation (all manner of displacements within unconsolidated sediments and soils that are produced by the activity of organisms: Richter 1952) is recognized

\footnotetext{
*E-mail: francois@obs-banyuls.fr
}

as one of the major processes that affect aquatic ecosystem functions. Bioturbation causes the redistribution of particles and interstitial water in sediments, and therefore affects the physical, chemical and biological properties of the substratum (e.g. Davis 1974, Rhoads 1974, Rhoads et al. 1978, Aller \& DeMaster 1984, Eckman 1985, Gérino 1990, Meadows \& Meadows 1991, Gilbert et al. 1995, 1996). In particular, bioturbation 
affects fluxes of organic matter, nutrients and contaminants across the sediment-water interface and within the sediment column (e.g. Aller 1982, 1994, Kristensen \& Blackburn 1987, Gérino 1990, Kure \& Forbes 1997, Madsen et al. 1997). The characterization and quantification of bioturbational processes in sediments allow us to determine the fate of the matter that settles at the sediment surface, and are therefore of primary concern in biogeochemistry. Hence, several mathematical models have been developed to quantify these processes. The most popular of the currently used models for bioturbation are 1D advection-diffusion models (Goldberg \& Koide 1962, Guinasso \& Schink 1975, Robbins et al. 1979, Berner 1980, Fisher et al. 1980, Aller 1982, Boudreau 1986). In 1D models, sediment reworking by the different organisms of a macrobenthic community is integrated in 2 global terms - diffusion and advection. Although these models are good at fitting experimental data and quantifying bioturbation process which have occurred at a site, their efficiency in making predictions is limited. They do not link explicitly the actual sediment mixing events to the organism activities, and do not take into account the spatial heterogeneity of sediment mixing due to the spatial distribution of the different macrobenthic organisms. In response to the need for a better understanding and prediction of bioturbation process, we have developed a mechanistic model of particle reworking based on a functional approach to the various organisms that make up a community (François et al. 2001). The different functional groups comprise species that have analogous effects on major ecosystem processes (Chapin et al. 1992), and have been defined according to the different mixing modes of the macrobenthic species. The current bioturbation model uses 4 different elementary components (François et al. 1997) corresponding to the 4 functional groups described in the literature (e.g. Fisher et al. 1980, Boudreau 1986, Smith et al. 1986, Gardner et al. 1987), i.e. biodiffusors, regenerators, upward-conveyors and downward-conveyors. Each elementary model is a space- and timedependent mechanistic mixing model using ordinary differential equations to describe the changes over time of a tracer distribution in a $2 \mathrm{D}$ sediment section inhabited by a macrobenthic organism. The biodiffusor model and the 'active' stage of the regenerator model are based on a particle diffusion process throughout the sediment section reworked by the organism, while upward- and downward-conveyor models include non-local transport of particles (as defined by Boudreau 1986). The 'passive' stage of the regenerator model also describes non-local transport, with net movement of surface sediment to the bottom of burrows which have been abandoned. In the present paper, we define a new functional group, the 'gallery- diffusor' group, as distinct from strict biodiffusors, e.g. the amphipod Pontoporeia hoyi (Robbins et al. 1979) and the bivalves Ruditapes decussatus and Venerupis aurea (François et al. 1999). This group comprises organisms with particulate tracer distribution patterns similar to the diffusion profile, but whose sediment reworking is neither random nor local. Organisms that construct gallery systems in sediments are resposible for this type of reworking. We base the bioturbation model of these organisms on a combination of 2 processes: biodiffusion in the sediment layer containing very dense gallery systems, and non-local transport (i.e. biotransport) in the region of tube bottoms. We compare the performance of this new reworking model with the biodiffusor model classically used to describe such mixing by simulating the time and depth distribution of a particulate tracer deposited initially at the sediment-water interface and comparing it to tracer profiles obtained in laboratory experiments with a very common and abundant polychaete of the estuarine ecosystem, Nereis diversicolor (Nereidae). We also propose a quantification of the particle reworking process by $N$. diversicolor: while the perturbation effects on the sediment properties are recognized (Gilbert et al. 1994, 1997) the reworking activity has, until now, mainly been considered in relation to the geometry of its burrows (Lambert \& Retière 1987, Gérino \& Stora 1991, Miron 1991, Gérino 1992, Davey 1994).

\section{MATERIALS AND METHODS}

Experiments were conducted in the laboratory with the polychaete Nereis diversicolor (Gérino \& Stora 1991, Gérino 1992). Eight PVC cores (diameter $=8 \mathrm{~cm}$, length $=30 \mathrm{~cm}$, with an opening at $28 \mathrm{~cm}$ ) were filled to $25 \mathrm{~cm}$ with homogenized sediment collected from the same site as the polychaetes that had been sieved through a $1 \mathrm{~mm}$ mesh and frozen for $24 \mathrm{~h}$ to remove macrobenthos. Gérino et al. (1998) proved that the use of PVC cores in the laboratory does not alter the bioturbation processes of organisms. Cores were placed in an oxygenated re-circulating seawater system. Water temperature was stabilized at $16^{\circ} \mathrm{C}$ and salinity at 30 . Of the 8 cores, 6 were colonized with $4 N$. diversicolor (wet weight of 0.3 to $0.6 \mathrm{~g}$ ); this corresponds to densities in the natural environment. The remaining 2 cores, without fauna, were used as control cores. The tracers used, the luminophores, were composed of natural sediment particles ranging in size from 10 to $250 \mu \mathrm{m}$ and dyed with luminescent paint; $1 \mathrm{~g}$ of luminophores was added to the sediment surface of each core at the beginning of the experiments, $1 \mathrm{~d}$ after organism addition. Experiments were stopped after $15 \mathrm{~d}$ for 4 cores (3 experimental and 1 control) and after $30 \mathrm{~d}$ for 
the remaining 4 (3 experimental and 1 control). For each core the luminophore numbers were determined in each sediment section $(1 \mathrm{~cm}$ intervals from 0 to $10 \mathrm{~cm}$ and $2 \mathrm{~cm}$ intervals from $>10 \mathrm{~cm}$ onwards) by counting (under UV light) the number in 2 replicate samples of $0.25 \mathrm{~g}$ dried sediment each. The results for each sediment section are expressed as percentage of the total amount of tracer in the whole core.

Gallery-diffuser model. We have designed a timeand space-dependent mixing model using ordinary differential equations, which describes the changes of a particulate tracer distribution in a 2D sediment section reworked by a gallery-diffusor organism, through time.

Functional diagram: As indicated in Fig. 1, the matrix consists of a sediment volume divided into sections of e units thickness, each section being divided into cells in 2 directions, vertical and horizontal. As a first approximation, the mixing process is considered invariable in relation to the sediment thickness. All cells are of the same size except those in the first row of the matrix. Their height, $b$, varies on the scale of local water cur-

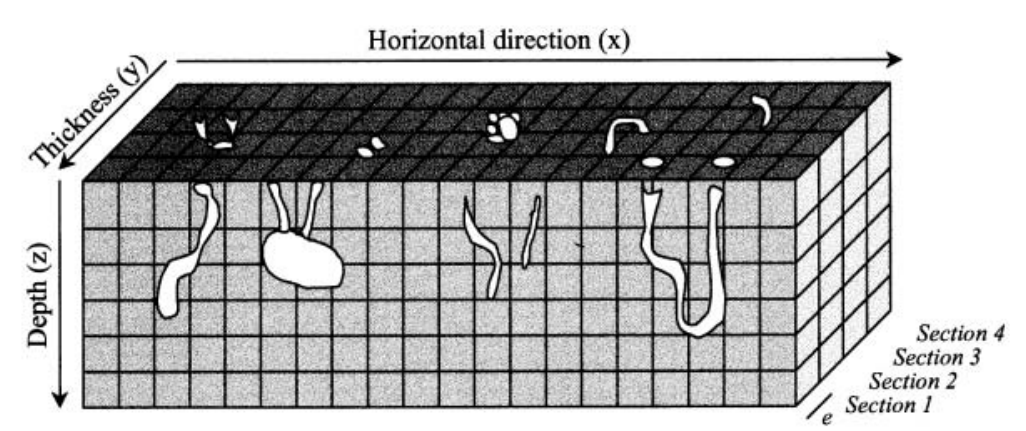

Section

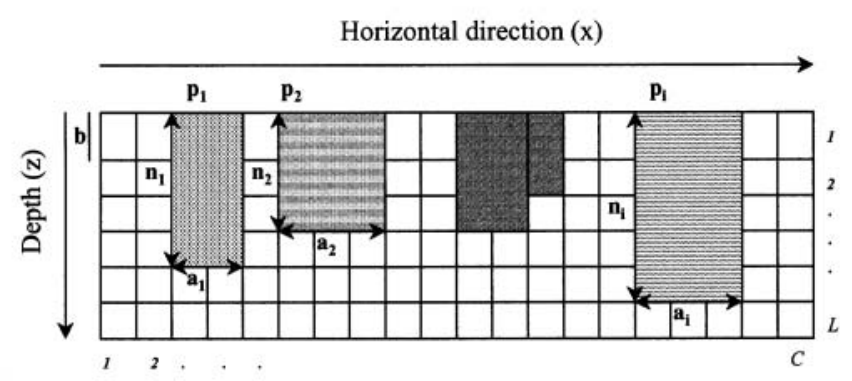

Fig. 1. Passage from the sedimentary column (3D: top graph) to the matrix of the functional diagram (2D: bottom graph). e: unit thickness of section; $p_{i}$ : position of organism $i$ in the matrix; $a_{i}$ : width of organism $i$ mixing zone; $n_{i}$ : depth of organism $i$ mixing zone; $b$ : height of first row of the matrix $L, C$ : total number of rows and columns of matrix respectively. Patterns differentiate the various functional groups of organisms rents which induce lateral mixing processes in the upper layer of the sediment. We assume that in a section, an organism, $i$, reworks the sediment of a zone $a_{i}$ cells wide and $n_{i}$ cells deep initially at cell $p_{i}$ located at the sediment-water interface. Each organism reworks its own part of the sediment according to the mixing mechanisms of its functional group and to its specific characteristics (e.g. depth of activity, mixing intensity). Fig. 2 describes different particulate material transfers induced by the activity of gallery-diffusor organisms in the sediment. These fluxes are schematized by arrows in the matrix in Fig. 3, which, for simplification, shows only exchanges at the sediment section between the cells $p-1$ and $p+a$. Physical mixing due to local water currents in Layer 1 induces particulate fluxes between adjacent cells of this layer and a loss of labeled material to the water column. In the upper layers, which are intensively drilled by organisms, we assume that the gallery-diffusor organisms generate diffusive mixing. In this area, a cell exchanges particulate material with its 4 nearest neighbors, except at the borders, where transfers are limited to cells inside the sediment reworking zone. Cells in the surface layer are also subject to physical mixing, output to the water column and loss of particles to the tube bottom. In the tube bottom zone, there is an accumulation of particles that have fallen down from the upper layer. These particles are equally shared among the cells of the biotransport zone. Biotransport arises from egestion of feces, maintenance of burrow lining, and the transport of particles to the tube bottom by animal movements.

Mathematical formulation: The notation is shown in Table 1. The mathematical formulation of the gallery-diffusor model describes the fluctuation of a quantity, $Q(l, c, t)$, of a tracer in 1 cell, located in the mixing zone of a gallery-diffusor individual, in row 1 , in column $c$ and at time $t$. The variation equation of this quantity is constructed by summing up the elementary variations due to the different perturbations affecting the cell, such as biodiffusion, physical mixing, output to the water column or tracer decay:

$$
\frac{\mathrm{d} Q(l, c, t)}{\mathrm{d} t}=\sum V_{i}
$$

Elementary variations, $V_{i}$, are listed in Table 2 for cells in the first row, between cells $(p+1)$ and $(p+a-2)$, and for cells in 


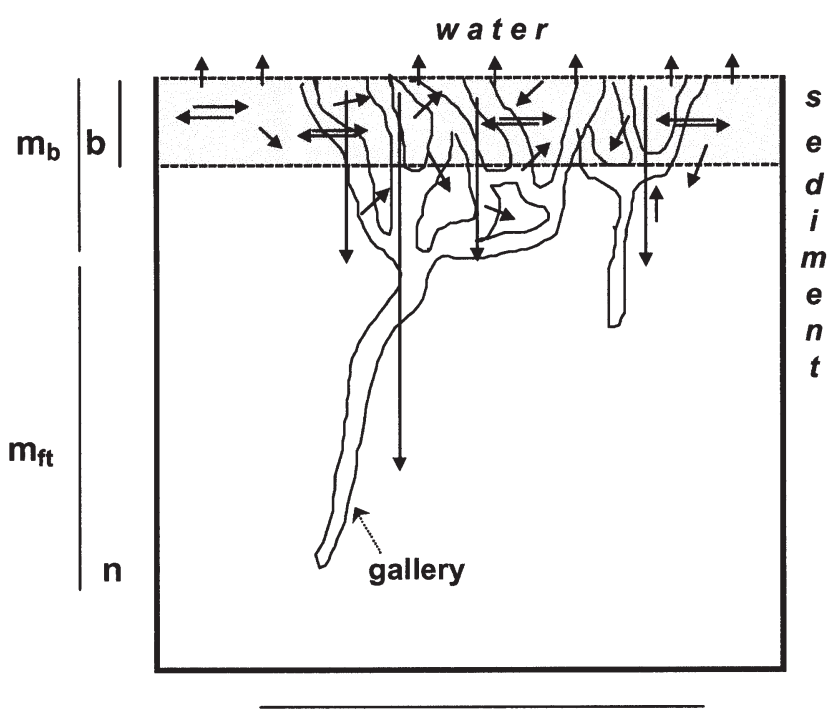

a

Fig. 2. Schematic of the physical and biological reworking processes of gallery-diffusor organisms. a: width of the organism mixing zone; $n$ : depth of the organism mixing zone; $m_{\mathrm{b}}$ : height of the biodiffusion zone; $\mathrm{m}_{\mathrm{ft}}$ : height of the tube bottom zone; $b$ : height of the first row of the matrix. Arrows indicate movement of sediment particles

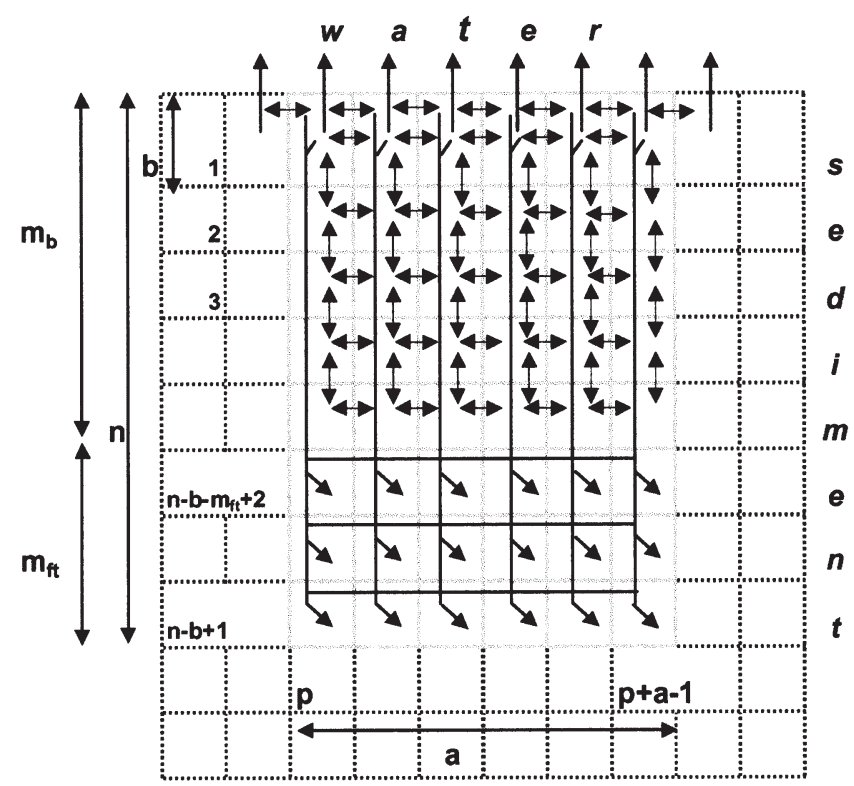

Fig. 3. Functional diagram of gallery-diffusor model. Arrows indicate fluxes between cells and between cells and water column. Decay is not schematized. Further details as for Fig. 2

Table 1. Notation used in the biodiffusor and gallery-diffusor models

\begin{tabular}{|ll|}
\hline Notation & \multicolumn{1}{c}{ Description } \\
\hline Variable & \\
Matrix parameters & \\
$L$ & Quantity of tracer contained in the cell in row $l$ and column $c$ at time $t$ (mass) \\
$C$ & \\
$b$ & Total number of rows in matrix (no. of cells) \\
$C$ & Total number of columns in matrix (no. of cells) \\
$l$ & Height of the first row (no. of cells) \\
Physical parameters & Number of the column considered \\
$D_{\mathrm{h}}$ & Number of the row considered \\
$f$ & \\
Biological parameters & \\
Position parameters & Physical diffusion rate in first layer due to local water currents (time ${ }^{-1}$ ) \\
$p$ & Output to the water column rate (time ${ }^{-1}$ ) \\
$a$ & \\
$n$ & \\
$m_{\mathrm{b}}$ & Organism position in matrix \\
$m_{\mathrm{ft}}$ & Width of organism mixing zone (no. of cells) \\
Mixing parameters & Depth of organism mixing zone (no. of cells) \\
$R_{\mathrm{d}}$ & Height of diffusion zone of the organism (no. of cells) \\
$R_{\mathrm{t}}$ & Height of tube bottom zone of organism (no. of cells) \\
Reaction parameters & Biodiffusion rate of organism (time ${ }^{-1}$ ) \\
$k$ & Biotransport rate of organism (time ${ }^{-1}$ ) \\
& \\
& Decay rate of tracer (time ${ }^{-1}$ ) \\
\hline
\end{tabular}


Table 2. Mathematical formulation of the elementary variations in tracer amount due to reworking by gallery-diffusors in cells of surface sediment (Row $l=1$ and column $[p+1] \leq c \leq[p+a-2]$ ) and of deep sediment (Row $[n-b+1] \leq 1 \leq$ $\left[n-b+m_{\mathrm{ft}}+2\right]$ and column $\left.p \leq c \leq[p+a-1]\right)$. Notation as in Table 1

\begin{tabular}{|ll|}
\hline Elementary variations & \multicolumn{1}{c|}{ Equation } \\
\hline Surface sediment & \\
Biodiffusive mixing & $-3 R_{\mathrm{d}} \times Q(1, c, t)+R_{\mathrm{d}}[Q(1, c-1, t)+Q(l, c+1, t)+Q(1+1, c, t)]$ \\
Biotransport & $-R_{\mathrm{t}} / a \times Q(l, c, t)$ \\
Physical mixing & $-2 D_{\mathrm{h}} \times Q(1, c, t)+D_{\mathrm{h}} \times[Q(l, c-1, t)+Q(1, c+1, t)]$ \\
Output to water column & $-f \times Q(l, c, t)$ \\
Tracer decay & $-k \times Q\left(l_{1}, c, t\right)$ \\
Deep sediment & \\
Biotransport & $+R_{\mathrm{t}} /\left(m_{\mathrm{ft}} \times a^{2}\right) \sum_{j=p}^{p+a-1} Q(1, j, t)$ \\
& \\
& $-k \times Q\left(l_{1}, c, t\right)$ \\
\hline
\end{tabular}

tracer in the other cells. In our experimental conditions, the sediment disturbance due to water currents at the sediment-water interface is negligible $\left(D_{\mathrm{h}}=0, f=0\right.$ and $\left.b=1\right)$ and the tracer is conservative $(k=0)$. Simulations were run using the gallery-diffusor model presented below and the biodiffusor model described by François et al. (1997). With the biodiffusor model, the sediment reworking due to organisms is considered to be analogous to a diffusion process through their entire mixing zone and is characterized by a biodiffusion rate, $R_{\mathrm{d}}$. For each model, numerical solutions of the variation equation were obtained using the Runge-Kutta method with steady-step (Press et al. 1992). Estimathe tube bottom zone. Therefore, the overall variation equation for the tracer quantity in a cell at the sediment surface is:

$$
\begin{aligned}
\frac{\mathrm{d} Q(l, C, t)}{\mathrm{d} t}= & -\left(k+f+2 D_{\mathrm{h}}+3 R_{\mathrm{d}}+\frac{R_{\mathrm{t}}}{a}\right) Q(l, C, t) \\
& \left.+\left(D_{\mathrm{h}}+R_{\mathrm{d}}\right)[Q(l, C-1, t)+Q(l, C+1, t)]\right) \\
& +R_{\mathrm{d}} Q(1+1, C, t)
\end{aligned}
$$

In the tube bottom zone, this variation equation becomes:

$$
\frac{\mathrm{d} Q(l, c, t)}{\mathrm{d} t}=\frac{R_{\mathrm{t}}}{m_{\mathrm{ft}} a^{2}} \sum_{j=p}^{p+a-1} Q(1, j, t)-k Q(l, c, t)
$$

We define 1 variation equation for each cell in the bioturbated zone. All are ordinary differential equations. Therefore, the model can be written as a set of the variation equations. More details about the construction of these equations are given in François et al. (1997).

Simulations. The matrix is divided into square cells (sides $1 \mathrm{~cm}$ long) according to the minimum thickness of the experimental sediment sections $(1 \mathrm{~cm})$. The matrix height is fixed at $25 \mathrm{~cm}$, which is the sediment core height, and its width at $50 \mathrm{~cm}$ to represent the $50 \mathrm{~cm}^{2}$ area of the core sediment section. We have assumed that the 4 Nereis diversicolor rework the whole sediment surface of the core. To simulate the experimental transient input of luminophores, at time $t=0$, at the sediment-water interface, we assume the following initial conditions:

$$
Q(l, C, 0)=f(l) \text { with } f(l)= \begin{cases}Q_{0} & \text { if } l=1 \\ 0 & \text { otherwise }\end{cases}
$$

At time $t=0$, we assume that the tracer is uniformly spread over the cells of row 1, i.e. $\sim 2 \%$ cell $^{-1}$ with no tions of the parameters $R_{\mathrm{d}}$ for the diffusor model and $R_{\mathrm{d}}$ and $R_{\mathrm{t}}$ for the gallery-diffusor model were obtained by minimizing a weighted sum of squared differences between observed and calculated concentrations of the the tracer. The weights are the inverse of the observed concentrations plus 1 to prevent a null denominator. The sum is:

$$
\sum_{i=\min }^{\max } \frac{\left(o b s_{i}-c a l_{i}\right)^{2}}{\left(o b s_{i}+1\right)}
$$

where $i$ is the number of the sediment layer or matrix row considered, min the first layer or first row number, max the deeper layer or the maximum row number, $o b s_{i}$ the amount of tracer measured in layer $i$ of the core and $\mathrm{Cal}_{i}$ the amount of tracer calculated in row $i$ of the matrix applying the biodiffusor or the gallerydiffusor model. This weighted least-squares criterion, using relative differences between observed and calculated concentrations, equalizes the low and the high concentrations when estimating the mixing parameters. This reinforces the importance of the low concentrations which occur at depth and reflect that part of the biotransport mechanism. The mixing parameters, $R_{\mathrm{d}}$ and $R_{\mathrm{t}}$, were adjusted by the downhill simplex method (Nelder \& Mead 1965).

\section{RESULTS AND DISCUSSION}

The luminophore profiles obtained in the colonized cores after 15 and $30 \mathrm{~d}$ are presented in Fig. 4, and the simulated profiles calculated for the same periods with the biodiffusor and the gallery-diffusor models are shown in Fig. 5. 


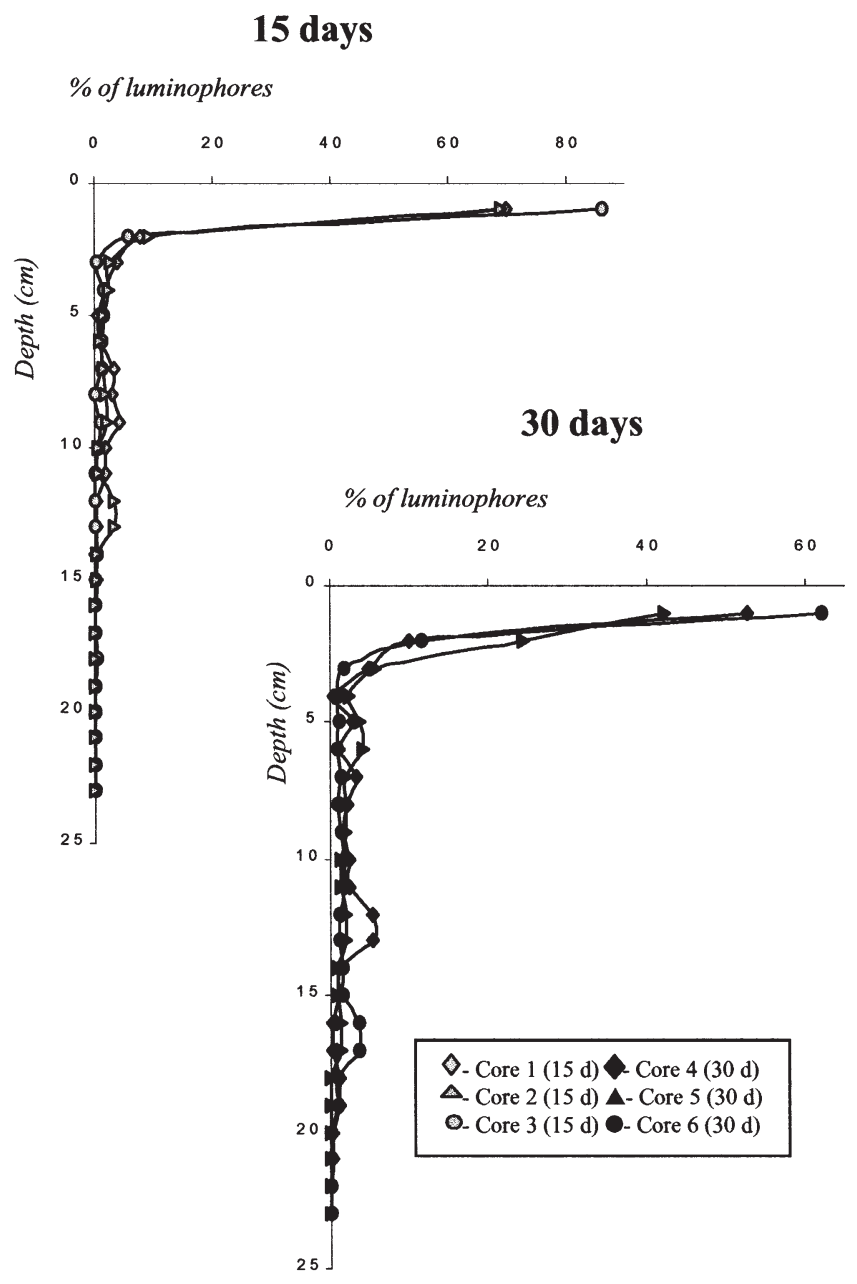

Fig. 4. Luminophore profiles measured in experimental cores inhabited by the polychaete Nereis diversicolor after $15 \mathrm{~d}$ (Cores 1, 2 and 3) and $30 \mathrm{~d}$ (Cores 4, 5 and 6). Data are percentages of total amount of tracer remaining in each core at end of the experiment

\section{Profiles}

In the reference cores, all the luminophores were still at the sediment-water interface at the end of the experiment. In the cores with Nereis diversicolor, luminophores were found down to $14.3 \mathrm{~cm}$ (range: 13 to $15 \mathrm{~cm}$ ) after $15 \mathrm{~d}$, and down to $18.3 \mathrm{~cm} \mathrm{(17} \mathrm{to}$ $19 \mathrm{~cm}$ ) after $30 \mathrm{~d}$. The profile shapes were similar; luminophore percentages decreased exponentially over the first $4 \mathrm{~cm}$, while at deeper levels, despite some fluctuations, the tracer showed quasi-uniform distribution. However, there were some variations between the different cores. After $15 \mathrm{~d}$, Core 3 appears to have been less reworked than Cores 1 or 2: more tracer remained in the upper layer (86 vs $69.9 / 69 \%$ for Cores $1 / 2$ ) and less tracer was buried below $4 \mathrm{~cm}$ (6.44 vs
16.5/16.6\% for Cores 1/2). Conversely, after $30 \mathrm{~d}$, one core, Core 5, appears to have been far more mixed in the first $4 \mathrm{~cm}$ than the other 2 cores (Cores 4 and 6): the percentage of tracer buried in the exponentially decreasing zone between 1 and $4 \mathrm{~cm}$, was $32.9 \%$ in Core 5 compared to 15.3 and $14.4 \%$ in Cores 4 and 6 , respectively. Therefore, in quantifying bioturbation, the cores have been treated separately.

Both the biodiffusor and the gallery-diffusor models were applied down to 15 and $19 \mathrm{~cm}$ for the 15 and $30 \mathrm{~d}$ periods, respectively, and the diffusion zone for the gallery-diffusor was limited to the first $4 \mathrm{~cm}$, according to the experimental profiles. Application of the biodiffusor model led to adjusted profiles, whereby the maximum depths of tracer present were 4 and $5 \mathrm{~cm}$ after 15 and $30 \mathrm{~d}$ simulation, respectively, compared to the 14.5 and $18.3 \mathrm{~cm}$ observed experimentally. The percentage of tracer below $4 \mathrm{~cm}$ was null after $15 \mathrm{~d}$ and varied from 0.01 to $0.02 \%$ after $30 \mathrm{~d}$ compared to the 6.44 to $16.59 \%$ and 23.48 to $31.98 \%$ observed experimentally. The tracer percentages decreased exponentially with increasing depth, and did not reflect the duality of the experimental profiles, which decreased exponentially in the upper layers and then showed a quasi-uniform distribution down to the maximum reworking depth. With the gallery-diffusor model, the adjusted profiles indicate the presence of tracer down to $15 \mathrm{~cm}$ after $15 \mathrm{~d}$ and $19 \mathrm{~cm}$ after $30 \mathrm{~d}$, the maximum depths measured in the colonized cores. The percentages of buried tracer varied from 4.81 to $14.30 \%$ after $15 \mathrm{~d}$ (6.44 to $16.59 \%$ in the colonized cores) and from 19.95 to $26.70 \%$ after $30 \mathrm{~d}(23.48$ to $31.98 \%$ in the cores). Moreover, the calculated profiles followed the patterns of the experimental data, decreasing exponentially in the first $4 \mathrm{~cm}$ and with quasi-uniform distribution down to as the maximum depth of sediment reworking by Nereis diversicolor.

A paired-sample $t$-test compared the fit to the experimental profiles of the diffusor model and of the gallery-diffusor model. The mean square deviation between the experimental and simulated luminophore percentages in the tube bottom zone of the cores was calculated, and the means obtained with the diffusor and the gallery-diffusor models were compared. We rejected the mean equality hypothesis at a significance level of 0.05 . The mean square deviation was far greater for the diffusor model than for the gallerydiffusor model. Therefore, the fit was clearly better with the gallery-diffusor model.

The gallery-diffusor mode of sediment reworking is consistent with the ethology of Nereis diversicolor. Its burrow system consists of large U-shaped burrows down to $16 \pm 2 \mathrm{~cm}$ depth (Gérino \& Stora 1991). Most of these burrows are extended by lateral branching in their upper part, creating Y-shaped burrows and 
increasing the tube density in the shallow sediment layer (Lambert \& Retière 1987, Gérino \& Stora 1991, Miron 1991, Gérino 1992, Davey 1994). It is assumed that building and maintaining these burrows generates intense multidimensional particle fluxes in the upper sediment layers, analogous to a diffusive particle pattern. Deeper down, the sparsity of the tubes precludes comparison of the mixing process with a diffusion phenomenon. The transport of particles at depth is assumed to occur through maintenance of the burrow lining (Aller \& Yingst 1978) and the rapid fall of surface sediment to the tube bottoms linked with worm movements (Goerke 1971, 1976, Reise 1979, Lambert \& Retière 1987, Esnault et al. 1990, Lambert et al. 1992). Thus, the presence of luminophores deeper in the sediment after $30 \mathrm{~d}$ than after $15 \mathrm{~d}$ must be due to a deeper burrowing of the organisms in the cores, perhaps linked to stressful conditions or simply to the acclimation time of the individuals in the sediment.

\section{Kinetic aspect}

While the simulated profile shape is important for judging the quality of the model, it is also interesting to compare the mode of particle transport which led to the experimental profiles. The mode of transport influences the time necessary for a particle to travel from one point to another, and thus determines the age of the particles at each depth. Fig. 6 shows the origin of the labeled materials which arrive instantaneously at the tube bottom area (between 5.5 and $6 \mathrm{~cm}$ ) at each time as calculated by the 2 models. The classical biodiffusive model indicates that $100 \%$ of the labeled particles which arrived in the 5.5 to $6 \mathrm{~cm}$ layer at time $t$ were in the 5 to $5.5 \mathrm{~cm}$ layer at time $(t-\Delta t)$ : particles which arrived at depth had first progressively transited through each level of the sedimentary column above. This is not the case with the gallery-diffusor model, which indicates $100 \%$ of the tracer which arrived in the layer 5.5 to $6 \mathrm{~cm}$ layer at time $t$ was at the surface layer at time $(t-\Delta t)$ : this model describes a direct influx of material from the upper layer into the deep layers. This mixing mode corresponds to a non-local transport as defined by Boudreau (1986, 1997), whereby sediment motions are not random but directed, and/or whereby the average distance traveled during mixing

\section{5 days}
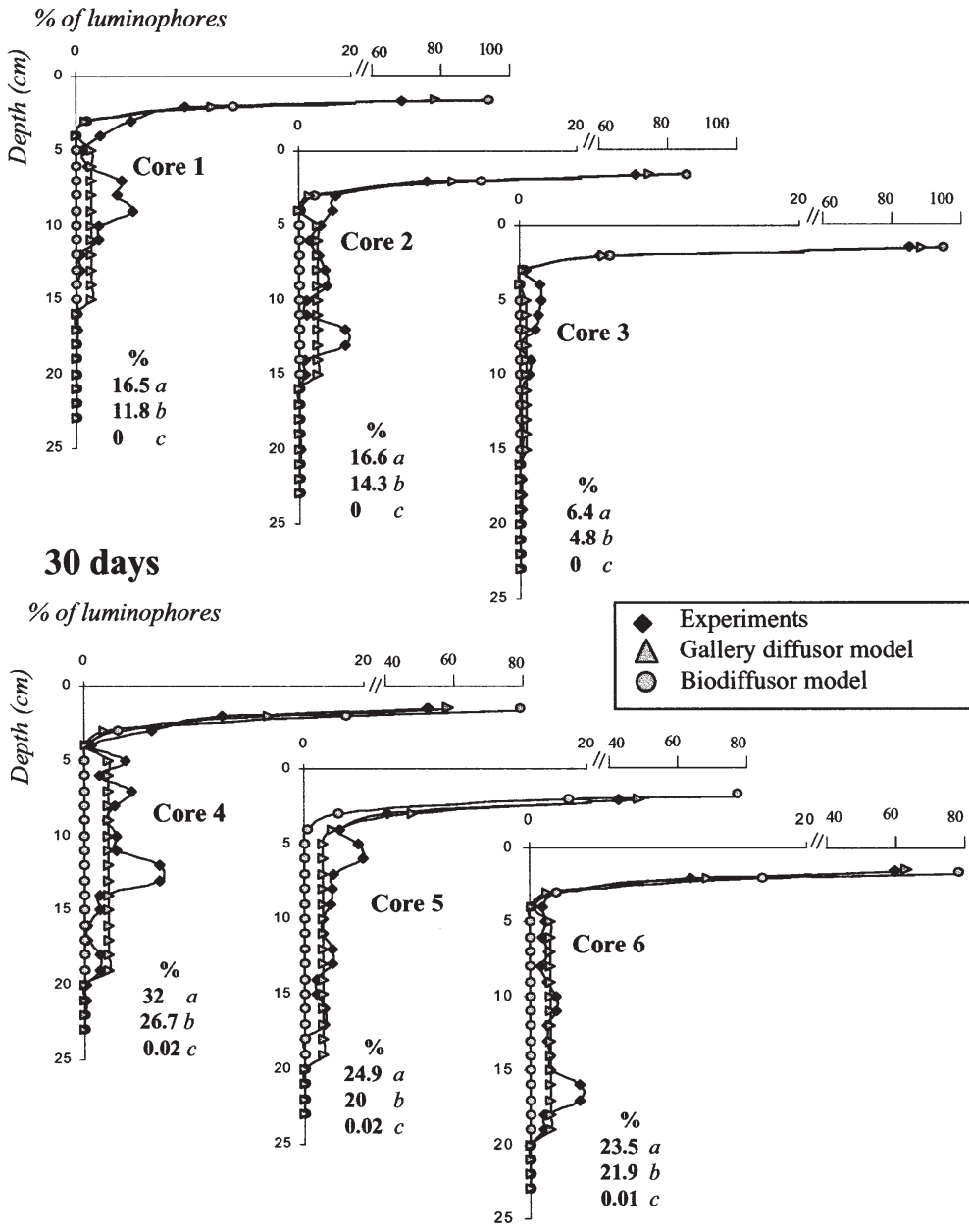

Fig. 5. Tracer profiles calculated by biodiffusor and gallery-diffusor models through adjustment of the experimental profiles obtained after $15 \mathrm{~d}$ (Cores 1,2 and 3) and $30 \mathrm{~d}$ (Cores 4, 5 and 6) in cores inhabited by the polychaete Nereis diversicolor. Data are percentages of total amount of tracer present in the matrix. Values below profiles are percentages of tracer buried below $4 \mathrm{~cm}$ for (a) experiments, (b) the gallery-diffusor model, and (c) the biodiffusor model events is essentially of the same order as the full mixed-layer depth. Similar observations were made by Aller \& Yingst (1978) with the polychaete Amphitrite ornata, which constructs a permanent multilayered U-shaped tube from particles obtained at the interface and transported to depth. The maintenance of its burrow walls introduces superficial material at every depth throughout the range of the burrow. The feeding behavior of the deposit-feeding species Nereis diversicolor (Goerke 1971, 1976, 1984, Fauchald \& Jumars 1979) also explains the rapid transport of surface material to depth: $N$. diversicolor rakes over the sediment surface around its tube mouth causing sediment to 


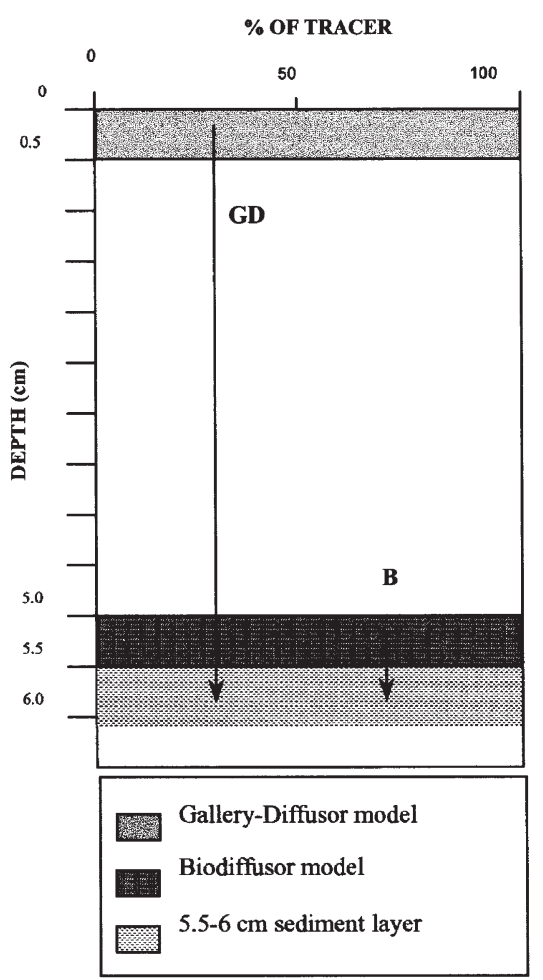

Fig. 6. Origin of the tracer which falls to the tube bottom area between 5.5 and $6 \mathrm{~cm}$ at each time with the biodiffusor (B) and gallery-diffusor (GD) models

fall down to the tube bottom (Goerke 1971, 1976, Reise 1979, Lambert \& Retière 1987, Esnault et al. 1990, Lambert et al. 1992).

\section{Parameter values}

In the model, the values of the parameters $R_{\mathrm{d}}$ and $R_{\mathrm{t}}$ $\left(\mathrm{d}^{-1}\right)$ depend on the cell size. The following transformation normalizes these parameters and expresses them as they appear in the literature:

$$
R_{\mathrm{d}}^{*}=R_{\mathrm{d}} \delta_{x}^{2}
$$

where $R_{\mathrm{d}}{ }^{*}$ is the normalized biodiffusion $\left(\mathrm{cm}^{2} \mathrm{~d}^{-1}\right), R_{\mathrm{d}}$ is the biodiffusion rate as used in our models $\left(\mathrm{d}^{-1}\right)$ and $\delta_{x}$ is the size of a cell $(\mathrm{cm})$. This transformation comes from the Fick laws (e.g. Ghez 1988, Wheatcroft et al. 1990), which introduce the definition of the diffusion coefficient in a 1D form: $D=$ $\delta^{2} / 2 T$, with $\delta$ being the step length that separates 2 points between which exchanges take place, and $1 / T$ being the frequency at which particles jump from one site to another. $R_{\mathrm{t}}^{*}$ is expressed as a speed of biotransport:

$$
R_{\mathrm{t}}^{*}=R_{\mathrm{t}} \delta_{\mathrm{X}}
$$

where $R_{\mathrm{t}}^{*}$ is the normalized biotransport rate $\left(\mathrm{cm} \mathrm{d}^{-1}\right)$, $R_{\mathrm{t}}$ is the biotransport rate $\left(\mathrm{d}^{-1}\right)$ and $\delta_{\mathrm{X}}$ is the size of a cell $(\mathrm{cm})$, as defined above. The adjusted values of the normalized parameters are presented in Table 3 for each core and for both models. The biodiffusion rates $\left(R_{\mathrm{d}}{ }^{*}\right)$ calculated with the gallery-diffusor model are linearly correlated $(r=0.997)$ with those obtained with the biodiffusor model. The values obtained with the gallery-diffusor model were always slightly lower than the biodiffusor values, and except for Cores 3 and 5, the values for the different cores were similar, ranging from $6.5 \times 10^{-3}$ to $11.1 \times 10^{-3} \mathrm{~cm}^{2} \mathrm{~d}^{-1}$ (mean $=$ $8.7 \times 10^{-3} \mathrm{~cm}^{2} \mathrm{~d}^{-1}$ ). There are no distinguishable mixing-parameter differences between the cores analyzed after $15 \mathrm{~d}$ (Cores 1 to 3 ) and $30 \mathrm{~d}$ (Cores 4 to 6). In Core 3 the biodiffusion rate was lower, 4.6 and $4.7 \times$ $10^{-3} \mathrm{~cm}^{2} \mathrm{~d}^{-1}$ whereas in Core 5 it reached 22.8 and $28.2 \times 10^{-3} \mathrm{~cm}^{2} \mathrm{~d}^{-1}$. This is consistent with the luminophore profile shapes observed. The biotransport rate $\left(R_{\mathrm{t}}^{*}\right)$ which was calculated with the gallerydiffusor model only gave similar values (8.9 to $11.5 \times$ $10^{-3} \mathrm{~cm} \mathrm{~d}^{-1}$; mean $=10.1 \times 10^{-3} \mathrm{~cm} \mathrm{~d}^{-1}$ ) for all cores except Core 3 . Here, as for the biodiffusion coefficient, the biotransport rate was low, $3.4 \times 10^{-3} \mathrm{~cm} \mathrm{~d}^{-1}$. The variations between cores could be due to individual variability in the mixing intensities of the different organisms or, more probably (since organisms of the same size were chosen), to survival and/or stress factors of the organisms in the in vitro cores.

\section{Conclusion}

The gallery-diffusor model provides mechanisms explaining, characterizing and quantifying sediment reworking by gallery-constructing macrobenthic organisms such as the polychaete Nereis diversicolor.

Table 3. Biodiffusion rate $\left(R_{\mathrm{d}}{ }^{*}: 10^{-3} \mathrm{~cm}^{2} \mathrm{~d}^{-1}\right)$ and biotransport rate $\left(R_{\mathrm{t}}{ }^{*}: 10^{-3} \mathrm{~cm} \mathrm{~d}^{-1}\right)$ of the biodiffusor (Dif) and gallery-diffusor (Gal) model, estimated from experimental luminophore profiles, obtained from in vitro cores inhabited by the polychaete Nereis diversicolor, after $15 \mathrm{~d}$ (Cores 1, 2, and 3) and $30 \mathrm{~d}$ (Cores 4,

\begin{tabular}{|c|c|c|c|c|c|c|c|c|c|c|}
\hline & \multirow{2}{*}{\multicolumn{4}{|c|}{$\begin{array}{l}-15 \mathrm{~d}- \\
\text { Core } 2\end{array}$}} & \multirow{2}{*}{\multicolumn{2}{|c|}{ Core 3}} & \multirow[b]{2}{*}{ Core 4} & \multirow{2}{*}{\multicolumn{2}{|c|}{$\begin{array}{l}-30 \mathrm{~d}- \\
\text { Core } 5\end{array}$}} & \multirow{3}{*}{$\begin{array}{l}\text { Core } 6 \\
\text { Dif } \mathrm{Gal}\end{array}$} \\
\hline & & & & & & & & & & \\
\hline & Dif & Gal & Dif & Gal & Dif & Gal & Dif Gal & Dif & Gal & \\
\hline$R_{\mathrm{d}}{ }^{*}$ & 9.3 & 8.5 & 11.1 & 10 & 4.7 & 4.6 & $9.2 \quad 7.2$ & 28.2 & 22.8 & $\begin{array}{ll}7.8 & 6.5\end{array}$ \\
\hline$R_{\mathrm{t}}^{*}$ & - & 8.9 & - & 11.1 & - & 3.4 & -11.5 & - & 9.9 & -9 \\
\hline
\end{tabular}
5 and 6) 
This new approach allows a closer fit of the simulated profiles to experimental data than the biodiffusor model. It includes tracer occurrence and therefore sediment reworking down to depths observed experimentally. The model provides a sediment reworking mechanism based on ethological observations. It allows for diffusive mixing of particles in the region of intense burrowing activity and the rapid transport of materials from the upper layer of sediment to the region of the tube bottom (i.e. 'biotransport'). This is not possible with the biodiffusor model, which represents particles as transiting progressively through each level of the sedimentary column before reaching the deep layer. Consideration of this biotransport process (which, in the case of $N$. diversicolor, can represent $32 \%$ of the surface material in $30 \mathrm{~d}$ ) is essential for understanding the distribution and the fate of organic matter or other non-conservative tracers. Although both the biodiffusor and the gallery-diffusor models lead to quasi-similar diffusive profiles, from a geochemical point of view they are not functionally equivalent; the reaction kinetics of many chemical species are in fact markedly affected by environmental conditions such as oxia or anoxia and by bacterial communities. The gallery-diffusor model constitutes 1 of the 5 elementary components in a global bioturbation model allowing the study of sediment reworking by macrobenthic communities according to their functional group and composition and/or to the specific characteristics of the organisms.

Acknowledgements. This work was supported by the G.D.R. HYCAR. (CNRS, Universite, Elf-Aquitaine).

\section{LITERATURE CITED}

Aller RC (1982) The effects of macrobenthos on chemical properties of marine sediment and overlying water. In: McCall PL, Tevest MJS (eds) Animal-sediment relations. Plenum Publishing Corp, New York, p 53-102

Aller RC (1994) Bioturbation and remineralization of sedentary organic matter: effects of redox oscillation. Chem Geol 114:331-345

Aller RC, de Master DJ (1984) Estimates of particle flux and reworking at the deep-sea floor using ${ }^{234} \mathrm{Th} /{ }^{238} \mathrm{U}$ disequilibrium. Earth Planet Sci Lett 67:308-318

Aller RC, Yingst JY (1978) Biogeochemistry of tube dwellings: a study of the sedentary polychaete Amphitrite ornata. J Mar Res 36:201-254

Berner RA (1980) Early diagenesis: a theoretical approach. Princeton University Press, Princeton, NJ

Boudreau BP (1986) Mathematics of tracer mixing in sediment. I. Spatially-dependent, diffusive mixing. II: Non local mixing and biological conveyor-belt phenomena. Am J Sci 286:161-238

Boudreau BP (1997) Diagenetic models and their implementation: modelling transport and reactions in aquatic sediments. Springer-Verlag, Berlin
Chapin FS, Schulze ED, Mooney HA (1992) Biodiversity and ecosystem processes. Trends Ecol Evol 7:107-108

Davey JT (1994) The architecture of the burrow of Nereis diversicolor and its quantification in relation to sedimentwater exchange. J Exp Mar Biol Ecol 179:115-129

Davis RB (1974) Stratigraphic effects of tubificids in profundal lake sediments. Limnol Oceanogr 19:466-488

Eckman JE (1985) Flow distribution by an animal tube mimic affects sediments bacterial colonisation. J Mar Res 43: 419-435

Esnault G, Retière C, Lambert R (1990) Food resource partitioning in a population of Nereis diversicolor (Annelida, Polychaeta) under experimental condition. In: Barnes $M$, Gibson RN (eds) Trophic relationships in the marine environment. Proc 24th Eur Mar Biol Symp. University of Aberdeen Press, Aberdeen, p 453-467

Fauchald K, Jumars PA (1979) The diet of worms: a study of polychaete feeding guilds. Oceanogr Mar Biol Annu Rev 17:193-284

Fisher JB, Lick WL, McCall PL, Robbins JA (1980) Vertical mixing of lake sediments by tubificid oligochaetes. J Geophys Res, 85:3997-4006

François F, Poggiale JC, Durbec JP, Stora G (1997) A new approach for the modelling of sediment reworking induced by a macrobenthic community. Acta Biotheor 45: 295-319

François F, Dalegre K, Gilbert F, Stora G (1999) Variabilité spécifique à l'intérieur des groupes fonctionnels: étude du remaniement sédimenatire de deux bivalves Veneridae, Ruditapes decussatus et Venerupis aurea. CR Acad Sci Ser III Sei Vie 322:339-345

François F, Poggiale JC, Durbec JP, Stora G (2001) A new bioturbation model for a functional approach to the sediment reworking tue to macrobenthic organisms. In: Aller JY, Woodin SA, Aller RC (eds) Organism-sediment interactions. University of South Carolina Press, Columbia, SC

Gardner LR, Sharma P, Moore WS (1987) A regeneration model for the effect of bioturbation by fiddler crabs on ${ }^{210} \mathrm{~Pb}$ profiles in salt marsh sediments. J Environ Radioact 5:25-36

Gérino M (1990) The effects of bioturbation on particle distribution in Mediterranean coastal sediment. Preliminary result. Hydrobiologia 207:251-258

Gérino M (1992) Etude expérimentale de la bioturbation en milieu littoral et profond. Quantification des structures de bioturbation et modélisation du remaniement biologique du sédiment. Thèse de Doctorat de l' Université AixMarseille II, Marseille

Gérino M, Stora G (1991) Analyse qualitative in vitro de la bioturbation induite par le polychète Nereis diversicolor. CR Acad Sci Ser III Sci Vie (3) 313:489-494

Gérino M, Aller R, Lee C, Cochran K, Aller J, Green M, Hirchberg D (1998) Comparison of different tracers to quantify bioturbation during a spring bloom: 234thorium, luminophores and chlorophyll-a. Estuar Coast Shelf Sci 46: $531-547$

Ghez R (1988) A primer of diffusion problems. John Wiley \& Sons, New York

Gilbert F, Rivet L, Bertrand JC (1994) The in vitro influence of the burrowing polychaete Nereis diversicolor on the fate of petroleum hydrocarbons in marine sediments. Chemosphere 29:1-12

Gilbert F, Bonin P, Stora G (1995) Effect of bioturbation on denitrification in a marine sediment from the West Mediterranean littoral. Hydrobiologia 304:49-58

Gilbert F, Stora G, Bertrand JC (1996) In situ bioturbation and hydrocarbon fate in an experimental contaminated 
Mediterranean coastal ecosystem. Chemosphere 33: 1449-1458

Gilbert F, Françoise F, Stora G, Bertrand JC (1997) Inhibition de la dénitrification par les hydrocarbures dans les sédiments marins. Rôle de Nereis diversicolor. CR Acad Sci Ser III Sci Vie 320:819-824

Goerke H (1971) Die Ernährungsweise der Nereis-Arten (Polychaeta, Nereidae) der deutschen Küsten. Veröff Inst Meeresforsch Bremerhav 13:1-50

Goerke H (1976) Nereis virens (Nereidae) Nahrungsaufnahme. In: Wolf G (ed) Encyclopedia Cinematographica. Institut für den wissenschaftlichen Film, Göttingen

Goerke H (1984) Temperature dependance of swarming in North Sea Nereidae. Fortschr Zool 29:39-44

Goldberg ED, Koide M (1962) Geochronological studies of deep-sea sediments by the ionium/thorium method. Geochim Cosmochim Acta 26:417-450

Guinasso NL, Schink DR (1975) Quantitative estimates of biological mixing rates in abyssal sediments. J Geophys Res 80:3032-3043

Kritensen E, Blackburn T (1987) The fate of organic carbon and nitrogen in experimental marine sediment systems. Influence of bioturbation and anoxia. J Mar Res 45:231-237

Kure LV, Forbes TL (1997) Impact of bioturbation by Arenicola marina on the fate of particle-bound fluoranthene. Mar Ecol Prog Ser 156:157-166

Lambert R, Retière C (1987) Etude de la territorialité chez les adultes de Nereis diversicolor (Annélide, Polychète). CR Acad Sci Ser III Sci Vie 305:643-647

Lambert R, Desrosiers G, Retière C, Miron G (1992) Activité de prospection de son aire d'alimentation par le polychète Nereis diversicolor (O. F. Müller): Données priliminaires. Cah Biol Mar 33:43-54

Madsen SD, Forbes TL, Forbes VE (1997) Particles mixing by the polychaete Capitella species. 1. coupling fate and

Editorial responsibility: Otto Kinne (Editor),

Oldendorf/Luhe, Germany effect of the particle-bound organic contaminant (fluoranthene) in a marine sediment. Mar Ecol Prog Ser 147: 129-142

Meadows PS, Meadows A (1991) The geotechnical and geochemical implications of bioturbation in marine sedimentary ecosystems. Symp Zool Soc Lond 63:157-181

Miron G (1991) Définition et description du domaine vital et biologie comportementale chez le polychète Nereis virens (Sars). Thèse PhD d'Océanographie, Département d'Océanographie, Université Quebec, Rimouski

Nelder JA, Mead R (1965) A simplex method for function minimization. Computer J 7:308-313

Press WH, Teukolsky A, Vetterling WT, Flannery BP (1992) Numerical recipes in FORTRAN; the art of scientific computing, Cambridge University Press, Cambridge

Reise K (1979) Spatial configurations generated by motile benthic polychaetes. Helgol Wiss Meeresunters 32:55-72

Rhoads DC (1974) Organism-sediment relations on the muddy sea floor. Oceanogr Mar Biol Annu Rev 12:263-300

Rhoads DC, McCall PL, Yingst JY (1978) Dirturbance and production on the estuarine seafloor. Am J Sci 66:577-586

Richter R (1952) Fluidal-texture in Sediment-Gesteinen und über Sedifluktion überhaupt. Notizbl Hess Landesamtes Bodenforsch Wiesbaden 3:67-81

Robbins JA, McCall PL, Fisher JB, Krezoski JR (1979) Effects of deposit feeders on migration of ${ }^{137} \mathrm{Cs}$ in lake sediments. Earth Planet Sci Lett 42:277-287

Smith JN, Boudreau BP, Noshkin V (1986) Plutonium and ${ }^{210} \mathrm{~Pb}$ distributions in Northeast Atlantic sediments subsurface anomalies caused by non local mixing. Earth Planet Sci Lett 28(1):15-28

Wheatcroft RA, Jumars PA, Smith CR, Nowell ARM (1990) A mechanistic view of the particulate biodiffusion coefficient: step lengths, rest periods and transport directions. J Mar Res 48:177-207

Submitted: December 9, 1998; Accepted: May 17, 2001 Proofs received from author(s): February 22, 2002 